\section{Distribution of Fluorosis in India and in England}

ExDEMIC fluorosis has been described in many different parts of tho world. Dental fluorosis is found with waters having a fluorine content of one part per million, and in tho United States considerable thought has been given to the elimination of 'mottled enamel' by improving water supplies'. Stiff backs and other signs of toxic fluorosis are found when the halogen exceeds three parts per million, and in North Africa, where the amount of fluorine in the soil is considerable, attention has been directed to the agricultural and veterinary, as well as to the human aspects of the problem². Industrial fluorosis among aluminium workers who handle cryolite has been described in Denmark ${ }^{3}$. In Arizona, Smith and others found that fluorine plus diet deficiency was a more potent cause of mottled enamel than fluorine alone.

India. Endemic fluorosis has been recognized among men and animals in the Madras Presidency, and fluorine has been found in the well water ${ }^{5}$. In the adjacent areas of the Nizam's dominions, I, with the assistance of Dr. B. K. Badami, director of Veterinary Services, Hyderabad, found dental fluorosis among children in the Mabubnagar district. The cattle, moreover, in this area develop bone lesions with exostoses, which clinically resemble those found among animals suffering from toxic fluorosis, incurred whilst grazing near aluminium factories in Denmark.

During the past few years I have examined more than 9,000 children in various parts. of the Punjab, and in certain clearly defined areas I have found evidence of dental fluorosis in the milk and permanent teeth. These areas include the eastern parts of the Mianwali district, villages near Sargodha, Hundewali near Chiniot, villages around Sangla Hill, in and around Kasur, villages near Ferozepore, and certain villages between Bhiwani and Hissar. I found that the teeth wero most 'mottled' among children from the lowest social classes, who showed also irregularity in the size of the individual teeth. Stiff backs and elbows have been observed among village children who used deep well water in the neighbourhood of Kasur ${ }^{8}$. The Irrigation Research Institute, Lahore, at my request, kindly had water from a number of wells in the Kasur area analysed, and obtained from nil to four parts fluorine per million.

All the places where dental fluorosis has been detected in the Punjab are situated on the Indo. Gangetic alluvium, which is of practically the same composition all over the Province, and there is no reason to suppose that this alluvium contains any fuorine ${ }^{7}$. Geodetic research, howover, has shown the existence of a ridge of rock causing shallowing of the alluvium ${ }^{8}$. The places from which I have collected records of clinical fluorosis may fairly bo said to lie over this buried ridge. Dr. Heron considers it is reasonable to think the rocks forming the ridge may include lavas, and associated granites and rhyolites.

England. Dental fluorosis has been described at Maldon and in certain other parts of Essex?. Essex waters have been found to contain fluorine up to six parts per million, and on a visit to that county I found that cases of mottled enamel may be met with in many different areas. Mottled teeth have also been described from parts of Somerset and Suffolk, and have been noted at Ashford, Kent, and at Leicester ${ }^{10}$, and in Derbyshire near Chesterfield ${ }^{11}$.

At Bampton, Oxfordshire, where I am living while on leave from India, I noticed dental fluorosis in

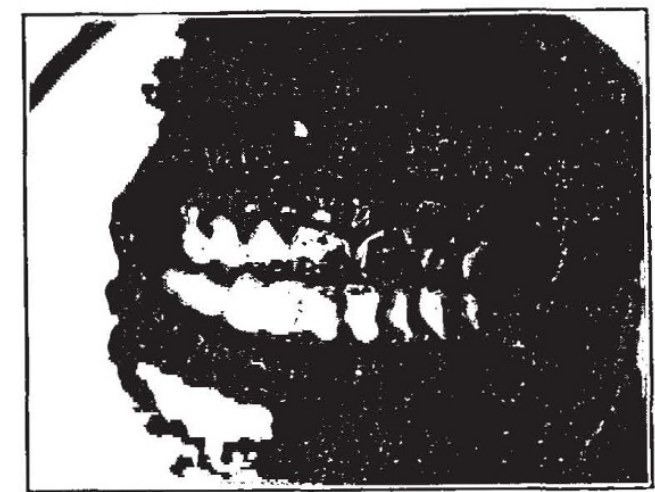

Dental fluorosis in Oxfordsime. E.G.B. Male, SEVENTEEN YEARS, BORN AND HAS LIVED ALL IIIS LIFE AT BAMipton IN THE BUSH. UNTIL THE AGE OF THIRTEEN YEARS DRANK WELL WATER.

adults and children in different parts of the village. Mr. Ainsworth very kindly came to Bampton and has confirmed my findings. Fluorine has now been found in Bampton well water. I have also recognized numerous cases of dental fluorosis among peoplo who have been born and spent most of their lives in the Marston Valley, Bedfordshire. Analysis has shown that the 'knotts' clay in the Marston Valley has a fluorine content of more than 450 parts per million. Wo do not know the source of the fluorine in the other parts of England whero human fluorosis is found. The brownish-yellow flecks and spots of pigment, together with the dull whito opaque areas of dental fluorosis are easily recognized, and if borne in mind, may be noted possibly in other areas.

Department of Medicine,

D. C. Wirson. Cambridge. June 21 .

${ }^{1}$ Dean, 3r. II. T., Office International d'hygiène publique, Bull. mensuel, 30, 1291 (1938). :Gaud, M., Ofice International d'hFgiène publique, Bull. mensuel,
3j, 1280 (1938).

"Roholm, K., "Fluorine Intoxication" (London: Lerris, 1937).

'Smith, M. E., Lantz, E. M., and Smith, H. V., "The Cause of Mottled Enamel, a Defect of Human Teeth", Oniv. Arizona Tech. Bull., No. 32 (1931).

s Shortt, II. E., McRobert, G. R., Barnard, T. W., and Nasar, A. S. M., Indian J. Med. Res., 25, 533 (1937).

- Stratford, L. E., personal communication (1939).

'Meron, A., personal communication (1938).

- Survey of India, Geodetic Report, Dehra Dun (1936).

- Ainsworth, N. J., Brit. Dental J., 233 (1933).

${ }^{10}$ Report of a meeting on May 18, 1933, of the British Dental Association, Metropolitan Branch.

"1 Donaldson, S. K., personal communication (1939).

\section{Insect Size and Temperature}

WHei an insect is reared at graded temperatures, it is commonly found that the size of the resultant offspring decreases with increasing temperature ${ }^{1}$. Evidence of the working of this principle in Nature has emerged in a study of the competition amongst the various organisms which scour and keep open the bacteria beds of sewage works ${ }^{2}$. Four species of these nematocerous Diptera have been systematically measured for eighteen months, the wing-length of the female being taken as a convenient criterion of size. The flies were trapped on the beds of Leeds and of Huddersfield sewage works, where the monthly mean bed temperatures have a range of abou' 